\title{
ANALISIS BIAYA DAN PENDAPATAN USAHATANI BERBAGAI KOMODITI HORTIKULTURA DI KECAMATAN GERUNG KABUPATEN LOMBOK BARAT
}

\section{ANALYSIS OF COST AND INCOME OF VARIOUS HORTICULTURAL COMMODITIES IN GERUNG SUB-DISTRICT OF WEST LOMBOK REGENCY}

\author{
Abdul Kadir ${ }^{*}$, Anwar $^{2}$, Ridwan ${ }^{2}$ \\ ${ }^{1}$ Program Studi Agribisnis Fakultas Pertanian Universitas Mataram, Mataram, Indonesia \\ ${ }^{2}$ Program Studi Agribisnis Fakultas Pertanian Universitas Mataram, Mataram, Indonesia \\ *Email Penulis korespondensi: kadirqqq902@gmail.com
}

\begin{abstract}
Abstrak
Penelitian ini bertujuan untuk mengetahui Biaya dan Pendapatan Usahatani berbagai komoditi hortikultura di Kecamatan Gerung Kabupaten Lombok Barat. Penelitian ini dilakukan dengan metode deskriftif, Penentuan desa sampel dilakukan secara Purposive sampling dan Penentuan jumlah petani responden dilakukan secara quota sampling sebanyak 75 orang. Metode analisis data yang digunakan dalam penelitian ini adalah dengan menggunakan Rumus analisis biaya dan pendapatan. Sementara untuk menghitung Kelayakan Usaha, rumus yang digunakan adalah Revenue Cost Ratio (R/C). Berdasarkan hasil penelitian diketahui usahatani berbagai komoditi hortikultura layak diusahakan, karena nilai R/Cdari semua komoditi yang diteliti lebih dari satu. Adapun permasalahan yang dihdapai oleh petani responden berbagai jenis sayuran di Kecamatan Gerung Kabupaten Lombok Barat diantaranya adalah hama/penyakit, pengairan, pupuk, obat-obatan, harga, dan iklim

Kata Kunci : Biaya, Pendapatan, komoditas hortikultura, Gerung.
\end{abstract}

\begin{abstract}
Research aims to know the cost and income farming various horticultural commodities in District Gerung West Lombok Regency. This research is done by the method of Deskriftif, sample village determination is done in Purposive sampling and determination of the number of farmers conducted by quota sampling as much as 75 people. The data analysis method used in this study is to use the formula for cost and income analysis. While calculating the business feasibility, the formula used is the Revenue Cost Ratio $(\mathrm{R} / \mathrm{C})$. Based on the results of the research is known farming various horticultural commodities are worth the effort, because the value of R/Cfrom All commodities are examined more than one. The problems that were struck by farmers respondents various types of vegetables in the district Gerung West Lombok District among others are pests/diseases, irrigation, fertilizer, medicines, prices, and climate

Keywords: Cost, Income, Horticulture Commodity, Gerung.
\end{abstract}

\section{PENDAHULUAN}

Indonesia merupakan negara agraris yang memiliki luas lahan pertanian yag sangat besar. Dengan sektor pertanian yang luas tersebut menjadikan pertanian sebagai sektor utama (leading sector) dalam pembangunan dan perekonomian Indonesia (Nursan \& Septiadi, 2020). Sektor pertanian tidak hanya mejadi penyedia kebutuhan bagi masyaraka Indonesia, tetapi juga menjadi sumber penghidupan bagi sekitar $50 \%$ penduduk. Pembangunan pertanian yang dikelola dengan baik akan dapat meningkakan pertumbuhan dan pemerataan ekonomi secara berkelajutan, mengatasi kemiskinan, dan penganggguran, yang pada akhirnya mensejahterakan masyarakat Indonesia secara keseluruhan (Kaman, 2005)

Ketahanan sektor pertanian dalam menghadapi krisis menyebabkan terjadinya perubahan pola pikir dari perencana pembangunan. Jika semula industrialisasi 
diandalkan sebagai suatu model pembangunan yang akan mampu memecahkan masalah keterbelakangan Negara-negara tersebut, pembangunan sektor pertanian kemudian menjadi harapan baru dalam pembangunan di masa sekarang. (Lukman \& Seotrisno, 2002). Sektor pertanian pada masa sekarang bukan hanya untuk memenuhi kebutuhan gizi saja akan tetapi juga mampu meningkatkan kesejahteraan masyarakat, salah satu sub sector yang memiliki potensi besar adalah subsektor hortikultura. Sub sektor hortikultura pada tahun 2017 menjadi kontributor penting dalam pembangunan ekonomi nasional. Peran strategis sub sector hortikultura terlihat dalam kontribusinya sebagai penyedia bahan pangan dan bahan bagu industri, penyumbang Produk Domestik Bruto (PDB), penyerap tenaga kerja, serta sumber pendapatan rumah tangga pedesaan. Berdasarkan data dari Badan Pusat Statistik Indonesia, PDB sub sektor hortikultura atas dasar harga berlaku pada tahun 2017 mencapai Rp.196,132 milyar dengan laju pertumbuhan sebesar 4,66 \% (Laporan Kinerja direktorat Jendral Hortikultura, 2017).

Kecamatan Gerung adalah salah satu Kecamatan yang berada di kawasan Kabupaten Lombok Barat yang Pengembangan usaha tani pada komoditi hortikultura sedang berkembang seiring dengan bertambahnya permintaan dan peluang ekonomi yang menjanjikan, maka banyak masyarakat yang mulai tertarik untuk melakukan budidaya tanaman hortikultura. Manfaat lain disamping meningkatkan pendapatan petani juga dimaksudkan untuk memenuhi kebutuhan vitamin dan mineral yang diperoleh dari hortikultura (Soekartawi,1995).

Seiring dengan bertambahnya tingkat permintaan komoditi hortikultura yang tidak diikuti dengan peningkatan jumlah produksi yang maksimal mengakibatkan harga pada komoditi hortikultura sering mengalami fluktuasi harga. Masalah yang biasanya mengakibatkan hal tersebut adalah keterbatasan modal, pemasaran, dan faktor iklim. Ketiga faktor ini saling berkaitan yang mempengaruhi tingkat produksi petani sehingga berdampak pada biaya dan pendapatan petani. Berdasarkan uraian diatas, maka perlu dilakukan penelitian yang berjudul "Analisis Biaya dan Pendapatan Berbagai Komoditi Hortikultura di Kecamatan Gerung Kabupaten Lombok Barat"

\section{METODE PENELITIAN}

Metode yang digunakan dalam penelitian ini adalah metode deskriptif. Metode deskriptif adalah metode menggunakan data statistik untuk menganalisis data dengan cara mendeskrifsikan atau menggambarkan data yang telah terkumpul sebagaimana adanya (Ridwan, 2007). Penelitian ini dilakukan di Kecamatan Gerung Kabupaten Lombok Barat Penentuan desa sampel dilakukan secara "Purposive sampling" di tiga desa yaitu Desa Gerung Selatan, Desa Tempos dan Desa Taman Ayu. Pemilihan ketiga Desa ini atas dasar memiliki petani hortikultura yang banyak di antara desa yang lain. Penentuan jumlah petani responden dilakukan secara Proporsional sampling sebanyak 75 orang dari jumlah populasi sebanyak 641 petani dari ke tiga desa tersebut.

Untuk mengetahui total biaya yang dikeluarkan untuk produksi tanaman hortikultura, maka dihitung dengan rumus sebagai berikut :

$$
\begin{aligned}
& \text { TC }=\text { TFC }+ \text { TVC } \\
& \text { Keterangan : } \\
& \text { TC }: \text { Total Biaya }(\mathrm{Rp}) \\
& \text { TFC : Biaya Tetap (Rp) } \\
& \text { TVC : Biaya Variabel (Rp) }
\end{aligned}
$$


Untuk mengetahui besar penerimaan yang diperoleh maka dilakukan perhitungan sebagai berikut :

$\mathrm{TR}=\mathrm{Y} \times \mathrm{Py}$

Keterangan :

TR : Total Penerimaan (Rp)

Y : Jumlah Produksi (kg)

Py : Harga $(\mathrm{Rp} / \mathrm{kg})$

Untuk mengetahui besarnya pendapatan yang diperoleh dalam usahatani tanaman hortikultura, digunakan rumus sebagai berikut

$\mathrm{Pd}=\mathrm{TR}-\mathrm{TC}$

Keterangan :

Pd : Pendapatan Usahatani (Rp)

TR : Nilai Produksi (Rp)

TC : Total Biaya $(\mathrm{Rp})$

Untuk mengetahui usahatani tersebut layak atau tidak untuk di usahakan dapat mengguakan rumus sebagai berikut

$\mathrm{R} / \mathrm{C}=\underline{\text { Penerimaan Total }(\mathrm{TR})}$

Dimana :

Biaya Total (TC)

Revenue $=$ Besarnya penerimaan yang diperoleh

Cost $=$ Besarnya biaya perhitungan

Ada tiga kriteria dalam perhitungan, yaitu :

a. Apabila $\mathrm{R} / \mathrm{C}>1$ artinya usahatai tersebut menguntungkan.

b. Apabila $\mathrm{R} / \mathrm{C}=1$ artinya usahatani tersebut impas.

c. Apabila $\mathrm{R} / \mathrm{C}<1$ artinya usahatai tersebut rugi.

Kendala dalam usahatani tanaman hortikultura di Kecamaan Gerung dijelaskan secara deskriptif, yang diperoleh dari hasil wawancara denga responden

\section{HASIL DAN PEMBAHASAN}

\section{Analisis Biaya dan Pendapatan Usahatani Berbagai Komoditi Hortikultura}

Pada setiap akhir panen petani memperoleh hasil prodiksi yang akan dijual dan menjadi penerimaan bagi petani. tetapi tidak semua penerimaan tersebut merupakan penerimaan dari petani. namun akan dikurangi dengan biaya-biaya yang digunakan.Proses produksi merupakanteknik untuk menghasilkan atau menambah kegunaan suatu barang atau jasa dengan sumber yang tersedia seperti sarana produksi, tenaga kerja, modal dan teknologi. Biaya (cost) adalah hasil dari semua input ekonomi yang diperlukan dan dapat diperkirakan untuk menghasilkan suatu produk atau nilai yang dinyatakan dengan uang dalam satuan rupiah (Rp). Biaya yang diperlukan merupakan suatu pengorbanan yang perlu dan dapat diperkirakan, dimana biaya yang digunakan dapat dipastikan pada saat pelaksanaannya, dan dapat diukur serta harus dapat dihitung jumlahnya dan dinyatakan dalam bentuk uang pada waktu penghitungan. Mulyadi (2007), mengemukakan bahwa biaya merupakan pengorbananyang diukur dengan satuan uang yang dilakukan untuk mencapai tujuan tertentu. Selengkapnya mengenai jumlah. biaya produksi. pendapatan. dan kelayakan pada usahatani akan dijabarkan dibawah ini. 
Tabel 1. Analisis Biaya Berbagai Komditi Hortikultura Kecamatan Gerung Kabupaten Lombok Barat Tahun 2019

\begin{tabular}{lcccccccc}
\hline No. & $\begin{array}{c}\text { Nama } \\
\text { Komoditi }\end{array}$ & $\begin{array}{c}\text { Luas } \\
(\text { ha })\end{array}$ & $\begin{array}{c}\text { Total } \\
\text { Biaya } \\
\text { Tetap } \\
(\mathrm{Rp})\end{array}$ & $\begin{array}{c}\text { Total } \\
\text { Biaya } \\
\text { Variabel } \\
(\mathrm{Rp})\end{array}$ & $\begin{array}{c}\text { Total } \\
\text { Biaya } \\
\text { Produksi } \\
(\mathrm{Rp})\end{array}$ & $\begin{array}{c}\text { Penerimaan } \\
(\mathrm{Rp})\end{array}$ & $\begin{array}{c}\text { Pendapatan } \\
(\mathrm{Rp})\end{array}$ & R/C \\
\hline & $\begin{array}{c}\text { Cabai } \\
\text { Rawit } \\
\text { Cabai }\end{array}$ & 0.13 & 824.125 & 2.915 .920 & 3.740 .044 & 17.720 .625 & 13.980 .581 & 4.74 \\
2 & $\begin{array}{c}\text { Besar } \\
\text { Kacang }\end{array}$ & 0.12 & 688.313 & 1.944 .253 & 2.632 .566 & 7.413 .833 & 4.781 .268 & 2.82 \\
3 & $\begin{array}{c}\text { Panjang } \\
4\end{array}$ & 0.13 & 586.500 & 2.407 .464 & 2.993 .964 & 6.424 .625 & $3.430,61$ & 2.15 \\
& Tomat & 0.13 & 391.472 & 2.204 .563 & 2.596 .035 & 6.623 .235 & 4.027 .201 & 2.55 \\
5 & Kangkung & 0.11 & 92.899 & 824.107 & 917.006 & 3.377 .500 & 2.460 .494 & 3.68 \\
\hline
\end{tabular}

Sumber: Data Primer Diolah Pada Tahun 2019

\section{Biaya Tetap}

Biaya tetap yaitu biaya yang besar dan kecilnya tidak tergantung pada besar kecilnya produksi, antara lain biaya penyusutan alat, biaya pajak, dan biaya sewa lahan. Alat-alat yang digunakan dalam usahatani hortikultura mengalami penurunan nilai atau penyusutan selama penggunaannya, nilai inilah yang termasuk dalam perhitungan komponen biaya pada table 4.6 menunujukkan bahwa rata-rata biaya tetap yang dikeluarkan oleh petani hortikultura cabai rawit adalah sebesar Rp. 824,125, Rp. 688,313 untuk cabai besar, Rp. 586,500 untuk kacang panjang, Rp.391,472 untuk tomat dan sebesar Rp. 92,899 untuk kangkung. Biaya terbesar pada penyusutan alat spayer/gembor yang memiliki harga tinggi, sehinggga penyusutan permusim tanam pun juga tinggi. Sedangkan untuk sewa lhan usahatani cabai rawit mengeluarkan baiaya paling besar yaitu sebanyak Rp. 489,583.33. Perbedaan jumlah biaya sewa lahan antar usahatani hortikultura disebabkan oleh perbedaan dalam luas lahan yang disewa oleh petani.

\section{Biaya Variabel}

Biaya variabel adalah biaya yang besar kecilnya tergantung dari besar kecilnya jumlah produksi dan luas lahan yang digunakan dalam usahatani komoditi hortikultura. Tabel 4.6 menunjukkan bahwa rata-rata biaya variabel yang dikeluarkan petani cabai rawit adalah sebesar Rp. 2,915,920, Rp. 1,944,253 untuk cabai besar, Rp2,407,464 untuk kacang panjang, Rp. 2,204,563 untuk tomat dan sebesar Rp. 824,107 untuk kangkung. Biaya variabel dalam usahatani Hortikultura itu sendiri terdiri dari biaya saprodi dan biaya tenaga kerja. Biaya tenaga kerja adalah biaya dengan pengeluaran terbesar dalam usahatani, dengan usahatani cabai rawit sebagai komoditi paling besar biayanya, yaitu sejumlah Rp 2,002,857.14.

\section{Penerimaan}

Penerimaan adalah nilai yang diperoleh dari hasil produksi dkalikan dengan harga yang berlaku. Besar kecilnya hasil panen komoditi hortikltura akan 
mempengaruhi langsung terhadap penerimaan hasil pada petani. Tabel 1 menunjukkan bahwa penerimaan petani cabai rawit adalah sebesar Rp. 17,720,625, Rp. 7,413,833 untuk cabai besar, Rp. 6,424,625 untuk kacang panjang, Rp. 6,623,235 untuk tomat dan sebesar Rp. 3,377,500 untuk kangkung. Diketahui bahwa penerimaan terbesar adalah dari komoditi cabai rawit. Hal ini sebabkan oleh permintaan yang tinggi, sedangkan ketersediaan cabai rawit dipasar terbatas.

\section{Pendapatan}

Pendapatan usahatani adalah selisih antara penerimaan usaha dengan pengeluaran tunai usaha dan merupakan ukuran kemampuan usahatani untuk menghasilkan uang. Berdasarakan hasil penelitian yang dilakukan pada petani responden. Dapat diketahui petani cabai rawit memperoleh pendapatan sebesar Rp. 13.980.580.85, cabai besar memperoleh pendapatan sebesar Rp. 4.781.267.56, Kacang Panjang sebesar Rp. 3.430.661.34, kemudian Tomat sebesar Rp. 4.027.201. dan untuk kangkung sebesar Rp. 3.430.661.

\section{Analisis R/C Ratio}

Untuk mengetahui tingkat kelayakan usahatani hortikultura dianalisis dengan menggunakan rumus Return Cost Ratio (R/C). Return Cost Ratio merupakan perbandingan antara penerimaan yang diperoleh petani hortikultura dengan total biaya yang dikeluarkan. dengan kriteria jika $\mathrm{R} / \mathrm{C} \geq 1$. maka usahatani kangkung efesien atau layak untuk diusahakan. sebaliknya apabila nilai $\mathrm{R} / \mathrm{C}<1$. maka usahatani tersebut tidak efisien atau tidak layak untuk diusahakan

Berdasarkan hasil perhitungan. dapat dilihat pada Tabel 14. bahwa rata-rata nilai $\mathrm{R} / \mathrm{C}$ ratio usahatani cabe rawit yang diterima petani adalah 4.74 artinya usahatani cabe rawit di Kecamatan Gerung Kabupaten Lombok Barat sangat layak untuk diusahakan. Dalam hal ini. setiap Rp.1.000 dari biaya yang dikeluarkan akan diperoleh penerimaan sebesar Rp.4.740.

Cabai besar merupakan komoditi hortikultura yang cukup banyak diusahakan oleh petani yang disebabkan oleh masih tingginya permintaan dari pasar. Sehingga petani tetap mengusahakan komoditi ini. Rata-rata nilai $\mathrm{R} / \mathrm{C}$ ratio usahatani cabe besar yang diterima petani adalah 2.82 artinya usahatani cabe rawit di Kecamatan Gerung Kabupaten Lombok Barat sangat layak untuk diusahakan. Dalam hal ini. setiap Rp.1.000 dari biaya yang dikeluarkan akan diperoleh penerimaan sebesar Rp.2.820.

Kacang panjang menjadi salah satu komoditi paling banyak permintaannya, hal ini dikarenakan masyarakat sudah mulai sadar untuk mengkonsumsi sayuran bergizi, dan salah satu sayuran yang memiliki tingkat gizi yang cukup tinggi adalah kacang panjang. Sehingga hal ini menjadikannya sebagai komoditi yang selalu diusahatanikan oleh petani. Berdasarkan hasil perhitungan. dapat dilihat pada Tabel 1. bahwa rata-rata nilai $\mathrm{R} / \mathrm{C}$ ratio usahatani kacang panjang yang diterima petani adalah 2.15 artinya usahatani cabe rawit di Kecamatan Gerung Kabupaten Lombok Barat sangat layak untuk diusahakan. Dalam hal ini. setiap Rp.1.000 dari biaya yang dikeluarkan akan diperoleh penerimaan sebesar Rp.2.150

Berdasarkan hasil perhitungan. dapat dilihat pada Tabel 1 bahwa rata-rata nilai $\mathrm{R} / \mathrm{C}$ ratio usahatani tomat yang diterima petani adalah 2.55 artinya usahatani cabe rawit di Kecamatan Gerung Kabupaten Lombok Barat sangat layak untuk diusahakan. Dalam hal ini. setiap Rp.1.000 dari biaya yang dikeluarkan akan diperoleh penerimaan sebesar Rp.2.550. rata-rata nilai $\mathrm{R} / \mathrm{C}$ ratio usahatani kangkung yang diterima petani adalah 4.66 artinya usahatani kangkung di Kecamatan Gerung Kabupaten Lombok Barat sangat layak untuk diusahakan. Dalam hal ini. setiap Rp.1.000 dari biaya yang dikeluarkan akan diperoleh penerimaan sebesar Rp.4.660 


\section{Permasalahan Petani Hortikultura}

Dalam menjalankan berbagai jenis usahatani. petani sering dihadapi dengan berbagai macam hambatan/kendala. sehingga mempergaruhi proses kelancaran produksi Berbagai Komoditi Hortikultura Kecamatan Gerung Kabupaten Lombok Barat.Berikut dibawah ini jenis kendala/hamabatan yang dihadapi petani responden dalam proses melakukan usahataninya.

Tabel 1. Distribusi Responden Berdasarkan Hambatan Yang Dihadapi Pada Komoditi Hortikultura di Kecamatan Kabupaten Lombok Barat Tahun 2019

\begin{tabular}{lll}
\hline Masalah & Jumlah Responden (Orang) & Persentase (\%) \\
\hline Hama dan Penyakit & 40 & 53.33 \\
Permodalan & 6 & 8.00 \\
Pupuk dan Obat-obatan & 10 & 13.33 \\
Iklim dan Pengairan & 12 & 16.00 \\
Harga & 7 & 9.33 \\
Total & 75 & 100.00 \\
\hline
\end{tabular}

Sumber : Data primer diolah tahun 2019

Berdasarkan hasil wawancara pada saat penelitian. masalah yang sangat mendasar yang dihadapi oleh petani hortikultura dikecamatan Gerung Kabupaten pengairan dan benih

a. Hama dan Penyakit

Hama dan Penyakit merupakan masalah utama yang dialami oleh petani responden dalam berusahatani. karena hama \& penyakit secara langsung mempengaruhi pertumbuhan dan perkembangan tanaman. Berdasarkan hasil penelitian $40(53.33 \%)$ petani responden menyatakan bahwa hama dan penyakit merupakan masalah yang dihadapi dalam melakukan usahatani hortikultura. Adapun jenis hama/penyakit yang sering ditemui oleh petani responden hortikultura anatara lain pada tanaman : ulat pemakan daun. kutu berwarna putih. layu. antrak dan kriting daun. ulat buah. ulat tanah. lalat buah. layu. lalat buah. kutu berwarna putih. bercak daun. antrak. dan layu. kutu hitam. ulat polong. ulat jengkal. karat daun dan bercak daun.

b. Permodalan

Berdasarkan hasil penelitin 6 orang atau $8 \%$ petani responden menyatakan bahwa modal sebagai masalah dalam usahatani hortikultura. Kurangnya modal merupakan salah satu kendala yang dihadapi oleh beberapa petani dalam menjalankan usahataninya. Hasil yang sama juga ditemukan pada penelitian Utama FR \& Nursan (2020) dimana modal masih menjadi masalah dalam usahatani. Kendala kurangnya modal pada penelitian ini disebabkan beberapa faktor yang dihadapi oleh petani seperti harga benih yang mahal, kurangnya ketersediaan pupuk yang beredar dimasyarakat sehingga menyebabkan harga pupuk cukup tinggi. obat-obatan pertanian pun menjadi masalah karena penggunaan obat sebagai pengendali hama/penyakit belum sesuai dengan hama/penyakit yang menyerang dalam artian obat yang beredar belum cukup kuat untuk mengatasi hama/penyakit yang menyerang tanaman akibatnya petani responden menggunakan sebagian modal usaha yang dimiliki untuk membeli obat terusmenerus dengan harapan hama/penyakit yang menyerang usahatani hortikultura dapat teratasi.

c. Pupuk dan Obat-Obatan

Pupuk merupakan penyubur tanaman yang ditambahkan ke tanah untuk menyediakan senyawa unsur yang diperlukan tanaman. Berdasarkan hasil penelitin 10 
orang atau $13.33 \%$ petani responden menyatakan bahwa pupukdan obat-obatan sebagai masalah dalam usahatani hortikultura. Pupuk menjadi masalah karena kurangnya ketersediaan pupuk dalam berusahatani. Berdasarkan hasil penelitian petani responden mendapatan pupuk dari dua sumber pertama yaitu dari pemerintah yaitu melalui kelompok tani. kedua membelinya langsung di toko penyedia sarana produksi di daerah terdekat. Pupuk yang diperoleh dari pemerintah melalui kelompok tani di bagikan pada anggota berdasarkan jumlah luas lahan yang terdata. bila pupuk yang diterima telah habis digunakan petani (kelompok tani) membuat surat permohoan bantuan pada pemerintah. Namun distribusi pupuk permohonan tersebut menjadi masalah dalam usahatani karena keterlambatan datang. sebagai akibat keterlambatan tersebut petani responden membeli pupuk di toko penjual sarana produksi di desa masing-masing

Obat-Obatan adalah salah satu dari berbagai macam masalah utama bagi petani responden. menyatakan obat-obatan sebagai permaslahan yang sedang dihadapi. Obatobatan menjadi maslah dikarenakan sudah tidak mempan terhadap serangan hama. sehingga petani mengggunakan dosis yang lebih banyak yang berefek pada pengeluaran modal untuk memenuhi kebutuhan oabat-oabatan meningkat

\section{d. Iklim dan Pengairan}

Berdasarkan hasil penelitian 12 petani atau $16 \%$ petani responden menyatakan iklim adalah hambatan bagi usahatani hortikultura. perubahan iklim yang ahir-akhir ini sering tak bisa ditebak membuat terjadinya gagal panen. karena dengan perubahan yang tiba-tiba akan memicu timbulnya virus maupun peynakit pad atanaman yang masih belum bisa beradaptasi dengan iklim yang berubah seketika

Berdasarkan hasil penelitian petani responden menyatakan pengairan sebagai masalah saat mengusahakan usahatani hortikultura. hal ini berkaitan dengan pembagian air bendungan. Beberapa tahun terakhir air menjadi masalah bagi petani di Kecamatan gerung yang berefek pada tingkat produksi. Hal ini disebabkan musim kemarau panjang yang terus menerus terjadi beberapa tahun belakangan

e. Harga

Berdasarkan penelitian 7 petani atau $9.33 \%$ petani responden menyatakan harga adalaha salah satu hambatan bagi mereka dalam usahatani hortikultura. Sifat produk pertanian yang cepat rusak mengakibatkan petani harus segera menjual hasil panennya. ketika rusak maka akan mempengaruhi harga komoditi hortikultura tersebut. Hasil yang sama juga ditemukan pada penelitian Utama FR \& Nursan (2020) yang menyatakan bahwa ada permasalahan harga dalam melakukan usahatani.

\section{KESIMPULAN DAN SARAN}

\section{Kesimpulan}

Berdasarkan hasil penelitian maka dapat disimpulkan bahwa:

1. Total biaya rata-rata yang dikeluarkan oleh petani dari usahatani komoditi hortikultura (Cabe Rawit, cabe besar, kacang panjang, tomat, dan kangkung) di Kecamatan Gerung Kabupaten Lombok Barat yaitu untuk usahatani cabe rawit sebesar Rp. 3.740.044.15/LLG atau Rp. 27.962.946.89/ha, usahatani cabe besar biaya produksi rata-ratanya adalah sebesar Rp. 2.632.565.77/LLG atau Rp. 21.154.546.35/ha, usahatani kacang panjang rata-rata biaya yang dikeluarkan adalah Rp. 2.993.963.76/LLG atau Rp. 23.367.522.03/ha, usahatani tomat rata-rata biaya yang dikelurkan sebesar Rp. 2.596.034.78/LLG atau Rp. 9.614.485.01/ha, 
dan usahatani kangkung mengeluarkan rata-rata biaya sebesar Rp. 734.662.70/LLG atau Rp. 5.550.784.83. Sementara pendapatan usahatani cabe rawit sebesar Rp.13.980.580.85 /LLG atau Rp.104.527.707.31/ha. usahatani cabe Besar dengan pendapatan petani sebesar Rp.4.781.267.56/LLG atau Rp. 38.420.900.08 /ha. usahatani kacang panjang dengan pendapatan petani sebesar Rp. 3.430.661.24 /LLG atau Rp. 26.775.892.60 /ha. usahatani Tomat dengan pendapatan petani sebesar Rp.4.027.200.51/LLG atau Rp.30.427.737.21 /Ha. dan usahatani Kangkung dengan pendapatan petani sebesar Rp.2.642.837.30 /LLG atau Rp.19.968.104.06/Ha.

2. Kelayakan Finansial atau $\mathrm{R} / \mathrm{C}$ ratio rata-rata usahtani Berbagai komoditi hortikultura di Kecamatan Gerung Kabupaten Lombok Barat layak dikembangkan karena nilai $\mathrm{R} / \mathrm{C}$ ratio cabe rawit adalah 4.74 , nilai $\mathrm{R} / \mathrm{C}$ ratio cabe besar adalah 2.15 , nilai $\mathrm{R} / \mathrm{C}$ ratio kacang panjang adalah 2.15. nilai $\mathrm{R} / \mathrm{C}$ ratio tomat adalah 2.55 dan nilai $\mathrm{R} / \mathrm{C}$ ratio kangkung adalah 4.60. secara keseluruhan maka berbagai sayuran tersebut layak untuk dikembangkan karena nilai R/C ratio lebih besar dari 1 .

3. Masalah yang dihadapi petani responden berbagai jenis sayuran di Kecamatan Gerung Kabupaten Lombok Barat diantaranya adalah hama/penyakit. pengairan. pupuk. obat-obatan. harga. dan iklim

\section{Saran}

Adapun saran yang dapat diberikan pada peneltian ini yaitu:

1. Agar pelaksanaan usahatani berjalan lancar tanpa hambatan diharapkan pada pemerintah untuk memperhatikan keadaan di lapangan. dengan cara memoptimalkan penyuluh dan kelompok tani serta juga memperhatikan alur distribusi pupuk

2. Untuk petani lebih memperhatikan lahan yang digarapnya. untuk menghindari permaslahan hama/penyakit. petani juga diharapkan lebih aktif untuk berkomunikasi dengan penyuluh pertanian.

\section{DAFTAR PUSTAKA}

Asrori. (2005). Analisis Pendapatan Usaha Tani Cabe Rawit di Kecamatan gerung Kabupaten Lombok Barat. Fakultas Pertanian. Universitas Mataram: Mataram

Prayitno, H \& Lincoln A.(1987). Petani Desa dan Kemiskinan. Badan Penerbit Fakultas Ekonomi Universitas Gadjah Mada: Yogyakarta.

Kaman \&Nainggolan. (2005). Pertanian Indonesia Kini dan Esok. Pustaka Sinar Harapan: Jakarta

Kardasan. (1993). Keuangan Pertanian dan Pembiayaan Perusahaan Pertanian Agribisnis. PT Gramedia Pustaka Utama: Jakarta

Soetrisno, L. (2002). Paradigma Baru Pembangunan Pertanian Sebuah Tinjauan Sosiologis.Kanisius: Yogyakarta

Mubyarto. (1989). Pengantar ekonomi pertanian. LP3ES: Jakarta

Mulyadi. (2012). Akutansi Biaya. Salemba Empat: Jakarta.

Nurmalinda. (2008). Analisis Pemasaran Beberapa Komoditi Sayuran Khas Dataran Tinggi Di Kecamatan Sembalun Kabupaten Lombok Timur [Skripsi]. Mataram. Fakultas Pertanian Universitas Mataram. 
Nursan, M., \& Septiadi, D. (2020). Penentuan Prioritas Komoditas Unggulan Peternakan di Kabupaten Sumbawa Barat. Jurnal Agribisnis Dan Ilmu Sosial Ekonomi Pertanian, 5(1), 29-34.

Ridwan. (2007). Skala Pengukuran Variabel-Variabel Penelitian. Alfabeta: Bandung

Rudi Hendri Wahyu Candra. (2015). Rentabilitas Usaha Pembenihan Hortikultura (Tanaman Cabai Besar dan Mentimun) System Polinasi Di Kecamatan Batukliang Utara Kabupaten Lombok Tengah [Skripsi]. Mataram. Fakultas Pertanian Universitas Mataram.

Sukirno, S. (2000). Pengantar Teori Ekonomi Mikro.PT. Raja Grafindo Persada: Jakarta Soekartawi.1995. Analisis Usaha Tani. Universitas Indonesia (UI-press): Jakarta.

Sunaryono H. (2008). Penghantar Pengetahuan Dasar Hortikultura. Sinar Baru Algensido: Bandung.

Utama FR, A. F., \& Nursan, M. (2020). Analisis Respon dan Faktor-Faktor yang Mempengaruhi Petani terhadap Penerapan Pertanian Organik di Kota Mataram. JIA (Jurnal Ilmiah Agribisnis) : Jurnal Agribisnis Dan Ilmu Sosial Ekonomi Pertanian, 5(3), 93-103. https://doi.org/10.37149/jia.v5i3.12140 